\title{
Dental care to the oncological patient in terminality
}

\section{Atenção odontológica ao paciente oncológico em terminalidade}

\author{
Karina da Costa Lima SOUTO' ${ }^{1}$ iD 0000-0003-1689-7425 \\ Diego Belmiro do Nascimento SANTOS ${ }^{2}$ iD 0000-0002-0109-6863 \\ Ully Dias Nascimento Távora CAVALCANTI ${ }^{1}$ iD 0000-0003-4748-1692
}

\begin{abstract}
End-stage cancer patients present many oral manifestations that need the support of a dentist, who included in the multidisciplinary team, must make the necessary adjustments in order to maintain the quality of life of these patients relieving their pain and suffering. Based on a literature review, the research searched articles published between June 2000 and February 2019, in the following databases: Pubmed, Scielo, Lilacs, Wiley Online Libary. The following inclusion criteria was used: articles published in Portuguese or English which included the keywords: dental care, critical care, palliative care, terminally ill. The aim of this paper is to present the importance of dental care to patients with cancer in palliative care. In conclusion, it was possible to verify that Dentistry in the hospital environment is of paramount importance, and should be based on empathy and communication, seeking to create the necessary bonds for the development of an effective and individualized treatment plan, discussion of cases in an integrated way and demonstrating the importance of higher education institutions in the training of future professionals. This paper aims to be contributory in order to increase the discussion about palliative care in Dentistry, besides providing subsidies to future studies that will deepen in this essential and still unexplored subject.
\end{abstract}

Indexing terms: Critical care. Dental care. Palliative care. Terminally ill.

\section{RESUMO}

Os pacientes oncológicos em estágio de terminalidade podem apresentar uma série de manifestações bucais que necessitam do suporte de um cirurgião-dentista. Incluído na equipe multidisciplinar, esse profissional deverá efetuar as condutas necessárias para manter a qualidade de vida desses pacientes, aliviando a sua dor e sofrimento. Baseado numa revisão bibliográfica, a pesquisa buscou artigos publicados entre junho de 2000 à fevereiro de 2019, nas bases de dados: Pubmed, Scielo, Lilacs, Wiley Online Libary. Utilizando os seguintes critérios de inclusão: artigos publicados em português ou inglês, que contemplaram os descritores: assistência odontológica, cuidados críticos, cuidados paliativos, doente terminal. O objetivo deste trabalho é apresentar a importância da atenção odontológica vltada para pacientes com câncer sob cuidados paliativos. Como conclusão, foi possível constatar que, a presença do cirurgião-dentista no ambiente hospitalar é essencial, e deve pautar-se na empatia e comunicação, buscando a criação de vínculos necessários para o desenvolvimento de um plano de tratamento efetivo e individualizado, fomentando a discussão dos casos de maneira integralizada e demonstrando a importância das instituições de ensino superior na formação dos futuros profissionais. Este trabalho visa contribuir em uma ampliação da discussão a respeito dos cuidados paliativos na odontologia, além fornecer subsídios a estudos futuros que irão se aprofundar nesta temática tão importante, mas, ainda, tão pouco explorada.

Termos de indexação: Cuidados críticos. Assistência odontológica. Cuidados paliativos. Doente terminal.

$\boldsymbol{\nabla} \mathbf{\nabla} \boldsymbol{\nabla}$

1 Faculdade Pernambucana de Saúde, Pós-graduanda em Oncologia Multidisciplinar. Av. Mal. Mascarenhas de Morais, 4861, Imbiribeira, 51150-000, Recife, PE, Brasil. Correspondência para / Correspondence to: KCL SOUTO. E-mail: <karinasouto@yahoo.com.br>.

2 Universidade Mauricio de Nassau, Faculdade de Odontologia. Recife, PE, Brasil.

$\boldsymbol{\nabla} \boldsymbol{\nabla} \boldsymbol{\nabla}$

How to cite this article

Souto KCL, Santos DBN, Cavalcanti UDNT. Dental care to the oncological patient in terminality. RGO, Rev Gaúch Odontol. $2019 ; 67: e 20190032$. http://dx.doi.org/10.1590/1981-86372019000323592 


\section{INTRODUCTION}

Cancer is the generic name used to describe a global health problem, characterized by a set of more than 100 diseases which have in common the rapid and disorderly growth of cells. These cells tend to be very aggressive and uncontrollable, determining the formation of tumors or malignant neoplasias, which invade tissues and organs and spread to various regions of the body [1]. According to estimates by the Globocan project, in 2012, the International Agency for Research on Cancer (IARC) and the World Health Organization (WHO), 14.1 million new cases of cancer and a total of 8.2 million deaths were reported. In Brazil, the estimate for 2015 was approximately 576 thousand new cases in men and women. In 2030, the developing countries, due to the growth and aging of the population, will be presenting 21.4 million new cases of cancer and 13.2 million deaths from the same disease [2].

Because cancer is a multifactorial disease, the multidisciplinary approach starting from its diagnosis has become essential in the fight against cancer. The dentist should be integrated with the treatment team, sharing his / her knowledge with other health professionals [3], contributing to the holistic vision that should be offered to the patient, in order to provide his / her well-being and dignity, preventing infections, reducing hospitalization time and medication use, as well as improving the quality of life and consequently its systemic condition [4].

Starting with the prevention while performing the adjustment of the oral environment through the cleaning and elimination of infection outbreaks, the role of the dentist should be to prevent and treat the oral manifestations that can affect the oncological patient in antineoplastic treatment, such as mucositis, xerostomia and candidiasis, and may also promote the speech rehabilitation, chewing and swallowing abilities through the facial obturator prosthesis.

Cancer can often grow to low cure potential. Within this teamwork, the dentist's role becomes crucial in the palliative care that can be offered to these patients. For the World Health Organization (WHO), in a concept defined in 1990 and updated in 2002 "Palliative Care consists of the assistance promoted by a multidisciplinary team, which aims to improve the quality of life of the patient and their relatives, facing a disease that threatens life by preventing and alleviating suffering, providing early identification, precise assessment and treatment of pain and other physical, social, psychological and spiritual symptoms".

In Dentistry, Palliative Care can be defined as the management of patients presenting progressive or advanced diseases due to the involvement of the oral cavity by the disease or its treatment, directly or indirectly. In the case of cancer patients, the symptoms may be specific to the disease process, the effects of medication or part of the general deterioration of the individual with the death proximity [5]. Nonetheless, Dentistry within palliative care is rarely mentioned and known. Despite the important oral manifestations developed, few scientific studies address the essential presence of the dentist supporting patients with end-stage cancer. The review of the literature discusses the main dental approaches, the profile of the dentist who should work with the multidisciplinary team and the peculiarities which define the treatment plan for these patients.

Dentistry in palliative care has been defined as the study and treatment of patients with active, progressive and very advanced disease, insofar as the oral cavity is compromised either by the disease directly or by its treatment, focusing quality of life [6-8]. A holistic view is fundamental to satisfactorily meet the diverse needs of terminally ill patients, allowing them a dignified death [9]. The incidence of oral complications in patients with endstage cancer is markedly elevated, due to worsening of systemic conditions and the occurrence of adverse drug reactions in the oral cavity $[9,10]$. Surgery, radiotherapy and chemotherapy, as treatment modalities offered for cancer, adversely affect oral health. The oral cavity can be considered a mirror of the general health of an individual [8].

In a study which evaluated the management of dental problems in 798 patients referred from different oncology departments, 50 (6.2\%) of these came from the medical oncology and palliative care department. It was concluded that this percentage corroborates the importance of dental care in improving the quality of life of cancer patients, regardless of the stage of the disease [11].

A person diagnosed with cancer is unlikely to consider the oral implications as a high priority, therefore dentists who work within palliative care should show empathy, be compassionate as well as excellent communicators [8]. 


\section{Communication and previous treatment}

Communication involves listening, empathy, and openness to dialogue. It begins with body language, facial expression, posture and position of hands. After introducing himself-herself, the professional should ask if he/she can sit next to the patient, either on the side of the bed, or on a chair, reinforcing the individual's presence beyond his or her oral cavity. The patient should be encouraged to discuss the presence or absence of pain and fear. It is only after a good communication has been established that an oral evaluation should be carried out [12]. Treatment options should be thoroughly explained and all doubts clarified. It is important that the patient is aware of the treatment that will be developed, this procedure will help him deal with the complications that may arise [6].

The period between diagnosis and treatment initiation is usually short. A comprehensive oral evaluation should be developed one month before the start of treatment. During anamnesis, medical and dental history should be collected. The intra-oral examination should be systematized and well detailed. The conditions of the teeth and soft tissues, tongue, palate and oropharynx should also be evaluated [6].

The largest salivary glands and the production, color and consistency of saliva are examined. Periodontal probing should be performed in order to evaluate the condition of the teeth present, and those which are associated with the tumor, in the direction of the radiation beam or with poor prognosis (deep cavities, periodontal pockets, non-vital teeth) should be extracted as soon as possible, in order to allow a minimum of 3 week- recovery before treatment begins. Scraping and prophylaxis, as well as debridement of plaque and calculus will reduce the risk of oral infections after therapy. The use of sodium fluoride preparations has to be emphasized. Carious teeth should be restored and root debris removed. Much emphasis should be given to maintaining oral hygiene [6]. The dentist's priority should be pain relief and infection prevention [13].

\section{Treatment of control of oral complications}

\section{Mucosite}

Mucositis is an extremely painful and debilitating condition, caused by the toxicity of radio and chemotherapy on tissues with a high mitotic rate, such as the oral mucosa
[14]. Usually it is presented within 5-7 days of initiation of treatment. Pain may be reduced through the use of topical anesthetics. Cleaning of the oral cavity should be severely emphasized as a means of preventing the worsening of the condition [15]. Pasty and liquid diet is advised as well as reducing the intake of hot and spicy foods. Harmful habits like smoking and alcohol are discouraged. Patients are encouraged to savor ice cubes. "Magic mouthwash", a combination of antihistamines, antifungals, topical anesthetics and even antibiotics may be prescribed $[6,7]$.

The severity scale of Mucositis provided by the World Health Organization (WHO), scores 0 when no abnormality is identified; the presence of erythema without the need for treatment characterizes the score 1; score 2 indicates the presence of painful symptoms without the need for analgesics with feeding difficulties; score 3 shows painful ulceration requiring the use of analgesics, and, finally, score 4 indicates necrosis requiring parenteral nutrition [14].

The use of low intensity laser in the oral cavity can prevent the occurrence of grade 3 mucositis. Laser therapy is known to present a biostimulating effect, modulating a variety of metabolic events, promoting analgesic, antiinflammatory and tissue repairing effect, accelerating the healing process [14].

\section{Xerostomia}

Patients undergoing radiation therapy undergo the destruction of the salivary glands within the treatment place. Due to decreased lubrication of the oral cavity, the tissues become more sensitive to trauma, ulcerated and prone to invasion of pathogens. Furthermore, one of the best side effects of medications used to control nausea and vomiting is xerostomia. Abundant fluid intake and the use of sugarless lozenges may aid in the stimulation of the residual gland. Saliva substitutes or artificial saliva can also be used for mouth lubrication $[6,7]$.

\section{Candidiasis}

Candidiasis is the most common fungal infection in patients who have received radiation therapy or chemotherapy. Its incidence in patients undergoing palliative care was estimated at $70 \%$ to $85 \%$, and is mainly a result of xerostomia. The patient should be severely 
educated about oral hygiene. The treatment of candidiasis can be topically or systemically performed. One of the most common topical agents used is clotrimazole. Nystatin may also be used topically as an oral suspension. Freezing nystatin with unsweetened fruit juices, producing popsicles or pieces of ice, may, in addition to the therapeutic effect of the medication, provide hydration to the patient's oral mucosa. Systemic antifungal agents such as ketoconazole and fluconazole may be used for more severe cases where topical therapy has not been sufficient $[6,7]$.

\section{Osteoradionecrosis}

Osteoradionecrosis is another well-known postradiation complication. The affected bone tissue becomes hypovascular and hypoxic, unable to repair or remodel being the jaw the most commonly affected. The risk for the development of osteoradionecrosis is considered lifelong. Traumas in the region should be severely prevented [6] and its treatment is a challenge. Nowadays, a new biotechnology has shown good results. A fibrin concentrate rich in platelets and leukocytes is applied to the affected area, accelerating angiogenesis and multiplication of fibroblasts and osteoclasts [16].

\section{Pain control}

Reducing pain discomfort or severity will be the greatest help that can be offered to a terminal patient. A key step in managing pain is a good anamnesis. Listen to the patient about the "cause" of the pain. It may be related to the disease, but sometimes it is associated with the psychological aspects of cancer. The real cause can only be discovered with a good conversation with the patient [6]. The evaluation should be individualized for each patient. The problem may require more radical management (surgical drainage, periodontal surgery, extractions), or a purely palliative treatment (control of pain in a topical or systemic way) [9].

\section{Rehabilitation}

Many patients who underwent surgical treatment of advanced maxillofacial malignancies may present, in addition to psychological trauma and social isolation, a deep aesthetic commitment, difficulties in speaking, swallowing and breathing. The dentist's action in the rehabilitation of these patients is of utmost importance, helping them to recover their quality of life. The rehabilitation proposal will depend on the location of the defect and the patient's prognosis. Prosthetic devices can be made in order to restore surgical defects of the oral cavity, or reproduce lost structures lost an eye or nose $[6,17]$.

\section{DISCUSSION}

The presence of a dentist within the multidisciplinary team of support to the cancer patient in palliative care is crucial, due to the oral needs presented by these patients. The main objective to be achieved is the quality of life. However, there is a lack of professional knowledge, since there has been no prior preparation during the Dentistry graduation courses that could provide the necessary knowledge about approaches aimed at patients and families facing cancer in a terminal state. Assessing the patient's holistic needs is one of the key recommendations in improving palliative care. After the diagnosis, the patient and his / her family can present many questions; the appropriate support that will be provided by the multidisciplinary team will depend on the ability to identify and address these needs and concerns [18].

The suitability of the oral medium before the start of antineoplastic therapies comes essential for the infection control. Oral hygiene instructions should be provided with a proper follow-up. Mucositis, xerostomia, candidiasis and osteorradionecrosis are the oral complications that most affect these patients. Mucositis is extremely painful and debilitating. For all oral complications, the dentist should develop a specific treatment plan, focusing on pain control and quality of life.

\section{FINAL CONSIDERATIONS}

Oncology patients undergoing palliative care need the support of a dentist who along with the multidisciplinary team, must be focus on the promotion of life quality. Higher education institutions should strive to promote the knowledge needed to train these professionals. Empathy and communication are of paramount importance, promoting the necessary bond between dentist, patient, family and multiprofessional team. 
Collaborators

KCL SOUTO, manuscript developing and, writing. DBN SANTOS, in charge of data analysis and paper writing. UDNT CAVALCANTI, in charge of data interpretation, manuscript revision and students's counseling.

\section{REFERENCES}

1. Instituto Nacional do Câncer. O que é câncer? [online]. Rio de Janeiro: INCA; 2019 [citado 2019 Jan 10]. Disponivel em: <https://www.inca.gov.br/o-que-e- cancer>.

2. Silva JAG. Estimativa 2014: incidência de câncer no Brasil. Rio de Janeiro: INCA; 2014.

3. Aranega AM, Bassi APF, Ponzoni D, Wayama MT, Esteves JC; Junior IRG. Qual a importância da Odontologia Hospitalar? Rev Bras Odontol. 2012;69(1):90-93.

4. Euzébio LF, Viana KA, Cortines AAO, Costa LR. Atuação do residente cirurgião-dentista em equipe multiprofissional de atenção hospitalar à saúde materno-infantil. Rev Odontol Bras Central. 2013;22(60):16-20.

5. Portal Educação. Cuidados paliativos em pacientes com câncer: o papel da Odontologia [homepage na internet]. [citado 2016 abr 10]. Disponível em: <http://www.portaleducacao.com.br/ odontologia/artigos/58698/cuidadospaliativos-em-pacientescom-cancer-o-papel-da-odontologia\#ixzz45oLkyvVW>.

6. Mol RP. The role of dentist in palliative care team. Indian J Palliat Care. 2010;16(2):74-8. http://dx.doi.org/10.4103/09 73-1075.68408

7. Wiseman M. The treatment of oral problems in the palliative patient. J Can Dent Assoc. 2006;72(5):453-8.

8. Thanvi J, Bumb D. Impact of dental considerations on the quality of life of oral cancer patients. Indian J Med Paediatr Oncol. 2014;35(1):66-70. http://dx.doi.org/10.4103/0971-58 51.133724

9. Rivera-Flores LG, Teja-Ángeles E, Durán-Gutiérrez LA. Manejo paliativo de manifestaciones estomatológicas en un paciente pediátrico con leucemia en etapa terminal. Reporte de caso clínico. Acta Ped México. 2015;36(2):97-104.

10. Ohno T, Morita T, Tamura F, Hirano H, Watanabe Y, Kikutani T. The need and availability of dental services for terminally ill cancer patients: a nationwide survey in Japan. Support Care Cancer. 2016;24(1):19-22. http://dx.doi.org/10.1007/s00520-0 15-2734-5

11. Das K, Krishnatreya M, Kataki AM. Pattern of referral and management of oro-dental problems in patients with cancer: a retrospective study. J Res Med Sci. 2014;2(4):1545-1547. http://dx.doi.org/10.5455/2320-6012.jjrms20141157

12. Wiseman MA. Palliative care dentistry. Gerodontology 2000;17(1):49-51. http://dx.doi.org/10.1111/j.1741-2358.20 00.00049.x

13. Chen X, Chen H, Douglas C, Preisser JS, Shuman SK. Dental treatment intensity in frail older adults in the last year of life. J Am Dent Assoc. 2013;144(11):1234-42. http://dx.doi. org/10.14219/jada.archive.2013.0051

14. Figueiredo ALP, Lins L, Cattony AC, Falcão AFP. Laser therapy in oral mucositis control: a meta-analysis. Rev Assoc Med Bras. 2013;59(5):467-474. http://dx.doi.org/10.1016/j.ramb. 2013.08.003

15. Saito H, Watanabe Y, Sato K, Ikawa H, Yoshida Y, Katakura A, et al. Effects of professional oral health care on reducing the risk of chemotherapy-induced oral mucositis. Support Care Cancer. 2014;22:2935-2940. http://dx.doi.org/10.1007/s0 0520-014-2282-4

16. Soydan SS, Uckan S. Management of bisphosphonate-related osteonecrosis of the jaw with a platelet-rich fibrin membrane: technical report. J Oral Maxillofac Surg. 2013;72(2):322-326. http://dx.doi.org/10.1016 / j.joms.2013.07.027

17. Haralur SB, Shah FK. Maxillofacial prosthesis in a palliative care for terminally ill patient with squamous cell carcinoma. BMJ Case Rep. 2013;2013:bcr2013009120. http://dx.doi. org/10.1136/bcr-2013-009120

18. Ghazali N, Kanatas A, Langley DJ, Scott B, Lowe D, Rogers SN. Treatment referral before and after the introduction of the Liverpool Patients Concerns Inventory $(\mathrm{PCI})$ into routine head and neck oncology outpatient clinics. Support Care Cancer. 2011;19(11):1879-1886. http://dx.doi.org/10.1007/s00520-01 $1-1222-9$

Received on: 31/5/2019

Final version resubmitted on: 19/10/2018

Approved on: 20/11/2018 